\title{
VÍZIKÖZMÜ-SZOLGÁLTATÁS ÉS A VÍZHEZ VALÓ JOG ÉRVÉNYESÜLÉSE MAGYARORSZÁGON
}

\author{
Szilágyi János Ede 80
}

Jelen írásomban azt tekintem át, hogy a magyar víziközmü-szolgáltatásról szóló törvény (Vksztv) vajon milyen formában járul hozzá - a korábbi tanulmányomban ${ }^{81}$ már részletesen vizsgált -vízhez való jog érvényre juttatásához. A Vksztv szabályozását - kiegészítve más jogszabályok kapcsolódó jogintézményeivel - természetesen egészében kell szemlélni, és az egész szöveget részleteiben bemutatva levonni a tanulságokat arról, hogy vajon a Vksztv biztosithatja-e a vízhez való jog érvényesülését. Mindezt szem elött tartva, jelen írásomban csak néhány rendelkezésre, illetve kapcsolódó jogszabályi elöirásra hívom fel a figyelmet.

Az első, amit megállapíthatunk, hogy a víziközmü-szolgáltatások kapcsán a jogalkotó maga is fontosnak tartja a szolgáltatásokhoz való diszkriminációmentes hozzáférést. Erre a Vksztv preambuluma is utal, kifejtve, hogy a Vksztv megalkotásának egyik indoka éppen „az objektív, átlátható és egyenlö bánásmód követelményének megfelelö szabályozás". A preambulumban hivatkozott követelményeket az Alaptörvény vonatkozó XV. és XXII. cikkei mellett részleteiben az egyenlő bánásmódról és az esélyegyenlőségről szóló 2003. évi CXXV. törvény (Egytv) foglalja magában. Utóbbi törvény maga kifejezetten nevesíti is a közszolgáltatások között a „vízszolgáltatást”, mint a „lakosság alapvető szükségleteinek ellátására irányuló szolgáltatást", és azt is, hogy személyi hatálya - a magyar államon, helyi önkormányzatokon és hatóságokon kívül, több más mellett - kiterjed a közszolgáltatást végző szervezetekre. ${ }^{82} \mathrm{Az}$ Egytv rendelkezéseinek végrehajtásában fontos szerep hárul az Egyenlő Bánásmód Hatóságára. ${ }^{83}$ A vízhez való jognak ez az egyik olyan eleme, amelynek érvényre juttatása Magyarország esetében is problémákkal terhes (lásd például a miskolci telepfelszámolási ügyet). ${ }^{84}$ Ehhez kapcsolódóan merül fel a kérdés, hogy a vízhez való jog érvényre juttatása (például az ivóvízhez való hozzáférés biztosítása) egyáltalán kinek is a felelössége a víziközmü-szolgáltatások esetén. A Vksztv elöírásainak elemzéséből az következik, hogy elsődleges felelőssége az ellátásért felelősnek van (adott település vonatkozásában lényegében az önkormányzatnak illetve az államnak) valamint a konkrét víziközmü-szolgáltatónak. Rajtuk kívül a Vksztv különböző rendelkezéseinek végrehajtásában, ezek ellenőrzésében fontos szerep jut a hatóságoknak, például a fogyasztóvédelmi hatóságnak illetve a Magyar Energetikai- és Közmü-szabályozási Hivatalnak (MEKH).

A vízhez való jog másik kardinális eleme a hozzáférhetöség kérdése. Ezzel összefüggésben maga a Vksztv tartalmaz számos részletszabályt. A lakossági felhasználókkal közvetlen kapcsolatban álló víziközmü-szolgáltatóknak - az ellátásért felelőssel kötött üzemeltetési szerződésben meghatározott keretek között, a víziközmü-rendszer teljesitöképességének mértékéig - a felhasználók részére víziközmü-szolgáltatást nyújt, és víziközmü-szolgáltatás

\footnotetext{
${ }^{80}$ Szilágyi János Ede, egyetemi docens, ME-ÁJK

${ }^{81}$ SzILÁGYI János Ede: Vízhez való jog - ábránd vagy immáron valóság? Közjavak, 1.évf. 1. szám, 2015 júliusszeptember, 38-41.

${ }^{82}$ Egytv 3-5. §

${ }^{83}$ Egytv $12-17 /$ A. $§$

${ }^{84}$ AJB-1474/2014. számú ügy.

http://www.ajbh.hu/documents/10180/2395518/miskolci jelentes 20150527.pdf/49568f34-d431-4112-a64f9e3a5e2babfd (letöltés:2015. október 20.)
} 
nyújtása céljából a szolgáltatást igénybe venni kívánók rendelkezésére áll. Abban az esetben, ha a víziközmű-rendszer teljesítőképességének szükössége miatt a különböző igények között súlyozni kell, akkor a lakossági felhasználói igények kielégítését kell előnyben részesíteni. ${ }^{85} \mathrm{~A}$ jogalkotó - a közszolgáltatási szerződés szolgáltató általi azonnali hatályú megszünése mellett - szigorúan határozta meg azt is, hogy a víziközmü-szolgáltató milyen korlátozó intézkedések megtételére jogosult. ${ }^{86} \mathrm{Az}$ ivóvíz-ágazat esetén a korlátozások bevezetésére egyáltalán - több más feltétel együttes fennállása mellett - akkor van mód, ha a víziközmü-szolgáltató e mellett is képes biztosítani a létfenntartási, a közegészségügyi és a katasztrófa-elhárítási vízigényeket. A közegészségügyi követelmények teljesítéséhez szükséges ivóvízellátás a Vksztv rendelkezése alapján akkor tekinthető biztosítottnak, ha az ivóvízellátás legalább $20 \mathrm{l} / \mathrm{fö} / \mathrm{nap}$ mennyiségben, négy emeletnél nem magasabb vagy lifttel rendelkező lakóépület esetén legfeljebb $150 \mathrm{~m}$ távolságon belüli, négy emeletnél magasabb lakóépületben pedig négy emeletnél nem nagyobb szintkülönbséggel járó vízvételezési lehetőséggel (közkifolyóról, tüzcsapról, szállított vízből) adott. (Ivóvizet kizárólag a közkifolyókról vételező természetes személyek számára pedig az ivóvízellátást legalább 20 liter/fö/nap mennyiségben, legfeljebb $300 \mathrm{~m}$ távolságon belül szükséges biztosítani). Korábbi írásomban már felhívtam a figyelmet az ENSZ biztonságos ivóvízhez és szanitációhoz való jog érvényesüléséért kijelölt biztosának álláspontjára, ${ }^{87}$ amely szerint a napi 20 liter per fó vízmennyiség csak a minimális létszükségletek fedezésére alkalmas, egy ilyen mennyiség mellett viszont még jelentős egészségügyi kockázatok lehetnek; ennek elkerülése - vagyis a vízhez való jog teljes érvényesülése - érdekében, megítélése szerint minimum 50 liter/fö/nap vízmennyiséget kellene biztosítani.

A Vksztv alapján a szükséges feltételek fennállása esetén korlátozó intézkedésként sor kerülhet lakossági felhasználókkal szemben például a közüzemi ivóvíz-szolgáltatás külön berendezés beépítésével időben és mennyiségben történő korlátozásával, a közüzemi ivóvízszolgáltatás felfüggesztésével (ha a létfenntartási és közegészségügyi vízigények teljesítéséhez szükséges ivóvízellátást a szolgáltató más, elérhető módon biztosítja), vagy - külön feltételek fennállása esetén - elörefizetős mérö elhelyezésével (hasonló korlátozások bevezetésére került sor például a nagy publicitást kapó avasi ,fészekrakó”ügyben). ${ }^{88}$ Mindezek mellett, a létfenntartási és közegészségügyi vízigényeknek eleget tevő ivóvízellátás érdekében a víziközmü-szolgáltató - az ellátásért felelős előzetes értesítése és a települési önkormányzat hozzájárulása esetében - a viziközmü tulajdonosának költségére közkifolyót helyezhet el. A közkifolyó üzemeltetésének költségeit a települési önkormányzat fizeti meg a víziközmüszolgáltató részére.

A villamos-energia- illetve a földgáz-közszolgáltatások mintájára a jogalkotó a Vksztv módosításával a víziközmü-szolgáltatások esetében is megalkotta a védendö felhasználó kategóriáját. Ezen esetben a felhasználók szociálisan rászoruló vagy fogyatékkal élő felhasználóként részesülhetnek a víziközmü-szolgáltató által nyújtott kedvezményben. A szociálisan rászorulók esetében ez különösen részletfizetést illetve fizetési haladékot jelenthet. ${ }^{89}$

A hozzáférhetőség kérdésében ugyanakkor kitérek majd arra, hogy konkrét ügyekben leginkább az okozott gondot, hogy egyrészt bizonyos emberek által lakott területekre már eleve nem is tervezik a víziközmü-szolgáltatás kiterjesztését, másrészt problémát okozhat,

\footnotetext{
${ }^{85}$ Vksztv51. §

${ }^{86}$ Vksztv 56-58. §; ilyen korlátozás megtételére például a szennyvízágazat lakossági felhasználóinál nincs is lehetősége a szolgáltatónak!

${ }^{87}$ http://sr-watersanitation.ohchr.org/pdfs/faq.pdf (letöltés:2015. október 20.)

${ }^{88} \mathrm{http}: / /$ miskolc.midip.hu/ujabb-atfogo-ellenorzes-az-avason (letöltés:2015. október 20.)

${ }^{89}$ Vksztv58/A-58/D. §
} 
amikor a víziközmủ-szolgáltatás nyújtásánál - lényegében a rendszerváltást követően kialakult bizonyos szerencsétlen jogi körülmények közrehatása miatt - közvetítő elem ékelődik a víziközmü-szolgáltató és a felhasználók közé.

Napjaink egyik aktuális kérdése a víziközmü-szolgáltatások esetében is a megfizethetöség kérdéséhez kapcsolódik. A Vksztv egy sor elvet tartalmaz a díjképzést érintően; így például a szolidaritás, a költségmegtérülés, illetve a legkisebb költség elveit. ${ }^{90}$ Ezen elvek alkalmazására a magyar jogalkotó egy hatósági áras rendszert vezetett be. A végleges verzió gyakorlati realizálódása jelenleg még folyamatban van. A díjmeghatározás végleges modellje szerint a díj összegét miniszteri rendeletben kell megállapítani a MEKH javaslatára. ${ }^{91}$

A víziközmü-szolgáltatás díjának kialakítása során figyelemmel kell lenni az EU elöírásaira is, amely esetében különösen a költségmegtérülés elve bír jelentöséggel. Az uniós költségmegtérülés elvének értelmezése ${ }^{92}$ nem minden nehézség nélküli, habár kétségtelen tény, hogy az EU Bíróság 2014. szeptember 11-ei döntése sokat segített a problémásabb rendelkezések megértésében. ${ }^{93}$ A költségmegtérülés elve alapján a víz árának a víziközmüszolgáltatások esetében is magában kell foglalnia a környezeti és a vízkészletekkel összefüggő kérdéseket (is). Az elv alkalmazása során a tagállamok ugyanakkor figyelemmel lehetnek a költségek megtérítésének szociális hatásaira. ${ }^{94}$ Korábban utaltam már ugyanakkor arra, hogy az ENSZ dokumentumok sem várják el a vízhez való jog ingyenes biztosítását a jogosultak számára.

A víziközmü-szakma és a téma iránt érdeklödők jelenleg tehát arra várnak, hogy mindezen körülményeket a víziközmü-szolgáltatások megfizethetősége kapcsán miként fogja tudni érvényesíteni a minisztérium. Fontosnak gondolom ugyanakkor hangsúlyozni, hogy a vízhez való jog alapján a víziközmü-szolgáltatás díjának (közkeletü nevén: vízdíjnak) nem minden határ nélkül kell megfizethetőnek lenni, hanem csak a vízhez való jog által előirányzott mértékben, vagyis - például a korábban elemzett ENSZ dokumentum, a 15. számú kommentár alapján - a meghatározott személyes és háztartási használatra. ${ }^{95}$ Ezen a körön túl más összegü vízdíj is érvényesülhet.

\footnotetext{
${ }^{90}$ Vksztv 1. $\S$

${ }^{91}$ Vksztv 62., 64-65., 76. §

${ }^{92}$ SZILÁGYI János Ede: A magyar víziközmü-szolgáltatások és a Vizkeretirányelv költségmegtérülésének elve.

Miskolci Jogi Szemle, 9. évf. 1. szám, 2014. 73-94.

${ }^{93}$ C-525/12. sz. ügy http://eur-lex.europa.eu/legalcontent/HU/TXT/?qid=1439147827166\&uri=CELEX:62012CJ0525 (letöltés:2015. október 20.)

${ }^{94}$ Lásd a Víz-keretirányelv 9. cikkét.

${ }^{95}$ http://www2.ohchr.org/english/issues/water/docs/CESCR GC 15.pdf (letöltés:2015. október 20.)
} 